\title{
Mitigation of Exterior Beam Rotation in Bridge Construction Through Experimental Investigation of Different Bracing Systems
}

\author{
Md. Ashiquzzaman ${ }^{1(\bowtie)}$, Li Hui $^{2}$, Ahmed Ibrahim $^{3}$, Will Lindquist ${ }^{4}$, \\ and Riyadh Hindi ${ }^{5}$ \\ ${ }^{1}$ Department of Civil Engineering, Aviation and Technology, \\ Saint Louis University, St. Louis, MO 63103, USA \\ ashiquzzamanm@slu.edu \\ 2 Parks College of Engineering, Aviation and Technology, \\ Saint Louis University, St. Louis, MO 63103, USA \\ huil@slu.edu \\ ${ }^{3}$ Department of Civil Engineering, University of Idaho, \\ Moscow, ID 83844, USA \\ aibrahim@uidaho.edu \\ ${ }^{4}$ Department of Civil Engineering, William Jewell College, \\ Liberty, MO 64068, USA \\ lindquistw@william.jewell.edu \\ 5 Department of Civil Engineering, Saint Louis University, \\ St. Louis, MO 63103, USA \\ rhindi@slu.edu
}

\begin{abstract}
Bridge contractors use different bracing systems to prevent exterior girder rotation in bridge construction. The reason behind this rotation is the unbalanced eccentric loads induced from loading the deck overhang, which can cause excessive twisting in the exterior girders and excessive overhang deflections. This situation can lead to several problems during construction and over the life of the bridge. Contractors traditionally use block-and-tie systems, which are formed by a combination of tie bars and timber blocks, to mitigate exterior girder rotation. However, block-and-tie systems do not always perform as expected and their efficiency to prevent rotation not yet been evaluated. This paper investigates current block-and-tie systems and presents an analysis of improved rotation prevention systems that can be implemented in the field. Both the block-and-tie systems and the new proposed bracing alternatives were tested in a twin steel girder system $[1.8 \mathrm{~m} \times 4.6 \mathrm{~m}(6 \mathrm{ft} . \times 15 \mathrm{ft}$. $)]$ that simulated a steel girder bridge bay. The prototype was eccentrically loaded at mid span through the application of a vertical load in a bracket which was mounted in one of the girders, simulating the loading from the bridge overhang. Forty-five bracing combinations were tested by varying the number of bracing elements and the spacing between them and obtaining girder rotation corresponding to the mid span of the loaded girder. The forty-five cases were divided into nine different groups to allow a clear and easy comparison between bracing alternatives. The results show very promising potential replacements of the current temporary bracing systems which, in many cases, offer minimal protection against exterior girder rotation.
\end{abstract}


Keywords: Deck overhang - Exterior girder rotation prevention - Stability issues $\cdot$ Block-and-tie systems $\cdot$ New bracing systems

\section{Introduction}

Rotation in exterior bridge girders occurs due to construction of the deck overhang, which is defined as the part of the deck that extends past the centerline of the exterior girder. In bridge construction, the deck overhang is generally formed with wood formwork supported on steel brackets that react against the exterior face of the exterior girder web, where the eccentric loads from the overhang cantilever (concrete, screed machine, construction workers) are directly transmitted (Fig. 1).

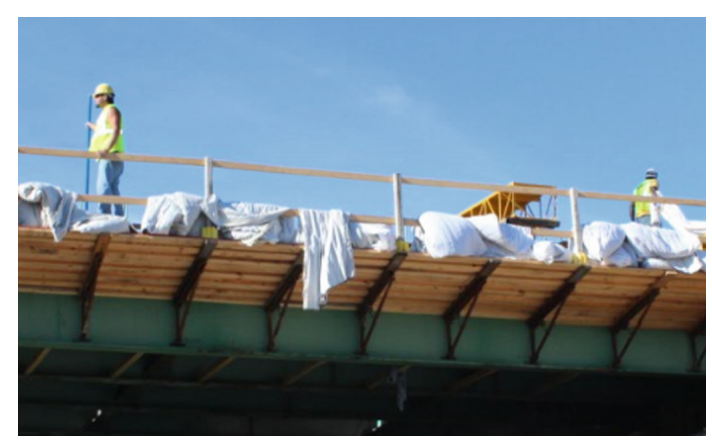

Fig. 1. Deck overhang in bridge construction

The unbalanced loads from the deck overhang can result in significant torsion applied to the exterior girders resulting in excessive overhang deflections which can create instability issues and problems with the finished grade of the concrete deck. These rotations occur in both concrete and steel girder bridges. Non-uniform deck thickness can lead to construction safety concerns (overturning failures, hazardous condition for construction personnel) and maintenance problems (premature deck cracking, long-term corrosion, deck steel reinforcement exposure) (Yang et al. 2010; Fasl 2008). In addition, local instability can be a major concern in steel plate girder bridges with large web slenderness values and initial imperfections (Shokouhian and Shi 2015; Gupta et al. 2006; Sayed-Ahmed 2005; Kala et al. 2009). Global buckling can also be a hazard if the tendency in rotation in the exterior girders is assumed to be a rigid body rotation (Yang et al. 2010; Haskett et al. 2009).

To mitigate exterior girder rotation in bridge construction, contractors use bracing systems formed by the combination of tie bars and timber blocks (block-and-tie systems). The ties (tension members) are normally placed from the exterior to the first interior girder with a transverse or diagonal configuration using hangers (Fig. 2), and the timber blocks (cross-Sect. $10.2 \mathrm{~cm}(4$ in.) $\times 10.2 \mathrm{~cm}(4$ in. $))$ are usually placed temporally during construction at the exterior panels between girder webs close to the bottom flanges of the girders (Fig. 3). However, block-and-tie systems do not always 
perform as expected and their efficiency to prevent exterior girder rotation has not been fully investigated. As a result, there is a lack of guidance provided by the Departments of Transportation (DOTs) regarding deck overhang design and construction. Contractors tend to base their designs on past experience and supplier recommendations.
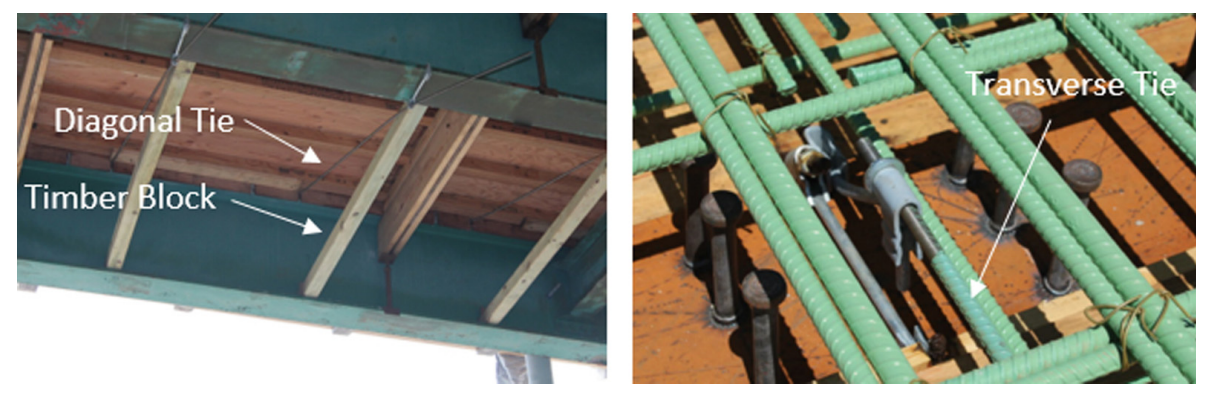

Fig. 2. Transverse and diagonal ties installed during bridge construction

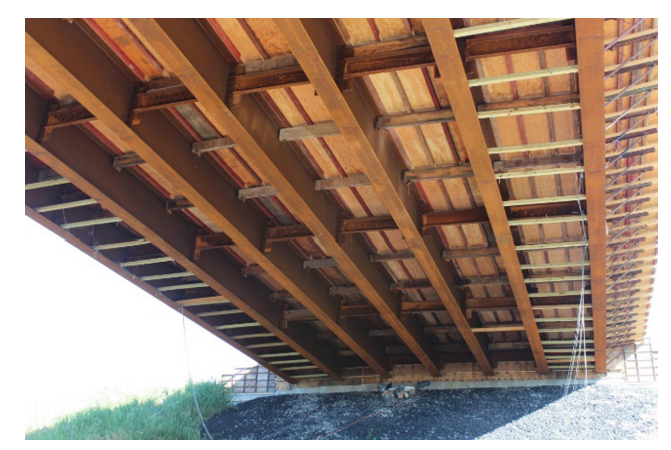

Fig. 3. Placement of timber blocks at the exterior panels of a bridge

One experimental study has been conducted to evaluate bracing systems for concrete girders (Yang et al. 2010). Suppliers have funded several experimental investigations in collaboration with DOTs to evaluate their products in concrete girders (Ariyasajjkorn 2006; Lackey 2006; Clifton 2008; Clifton and Bayrak 2008). However, and up to the knowledge of the authors, no previous experimental research has been implemented addressing the effectiveness of bracing systems for use with steel girder bridges, where the risk of stability issues is great in comparison to concrete girders.

Therefore, the present paper has two main expectations: (1) evaluation of the bracing systems currently implemented by contractors (block-and-tie systems) during bridge construction, and (2) analysis of improved rotation prevention systems that can be implemented in real bridge construction. Both the block-and-tie systems and the proposed bracing alternatives are tested experimentally using a twin steel girders system $[1.8 \mathrm{~m} \times 4.6 \mathrm{~m}(6 \mathrm{ft} . \times 15 \mathrm{ft}$. $)]$ that simulates a real steel girder bridge bay. 


\section{Test Setup}

The test setup to investigate the effectiveness of current and proposed exterior girder rotation prevention systems is shown in Fig. 4. The twin steel girder system consisted of two W533 $\times 65.5(\mathrm{~W} 21 \times 44)$ steel girders. The girders were $457 \mathrm{~cm}(15 \mathrm{ft}$. $)$ long connected in each corner to W356 $\times 122(\mathrm{~W} 14 \times 82)$ steel sections with a length of $91.44 \mathrm{~cm}(3 \mathrm{ft}$.$) . The \mathrm{W} 356 \times 122(\mathrm{~W} 14 \times 82)$ beams were connected through both flanges to threaded rods anchored to the strong floor with bolted connections. Bolts were used to connect the W533 $\times 65.5(\mathrm{~W} 21 \times 44)$ girders to the W356 $\times 122$ $(\mathrm{W} 14 \times 82)$ support beams. Two end cross frames spaced at $426.7 \mathrm{~cm}(14 \mathrm{ft}$.$) were$ also included at both ends of the setup.

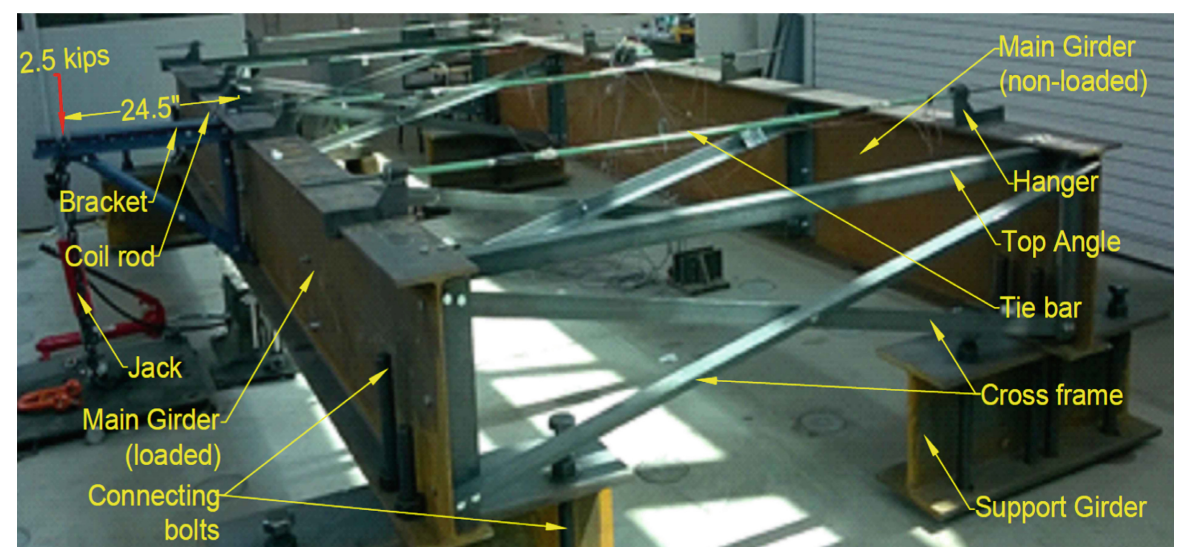

Fig. 4. Test setup

A point load of $11.12 \mathrm{kN}(2,500 \mathrm{lbs}$.) was applied to one girder (considered the exterior girder) to simulate the overhang construction loading that occurs during the construction of an actual bridge. A vertical point load was applied from a manually operated jack attached to the bracket with a steel chain. A hydraulic jack was connected to a load cell. The load cell was bolted to a reaction frame fixed to the strong floor. The load was applied gradually in five steps of $2.22 \mathrm{kN}(500 \mathrm{lbs}$.) each at the tip of the horizontal leg of the bracket at a distance of $62.23 \mathrm{~cm}$ (24.5 in.) from the centerline of the loaded girder.

The girders were instrumented with dual-axis tilt sensors at mid span (at top flange and web intersection) of loaded girder. The rotation in this location is the most relevant because it dictates the deflection of the deck overhang.

\section{Description of Rotation Prevention Systems}

\section{Tension Members}

Transverse Tie Bar (TT)

Two types of transverse tie bars are normally used in bridge construction including (1) No. 13 (No. 4) steel bars connected from one exterior girder to the other exterior 
girder at a spacing of $1.22 \mathrm{~m}$ (4 ft.), and (2) No. 13 (No. 4) steel bars which are

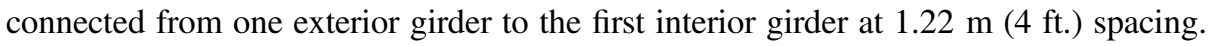
A twin steel girder system was used for this study resulting in no difference between these techniques. Schematic views of transverse tie bars are shown in Fig. 5.

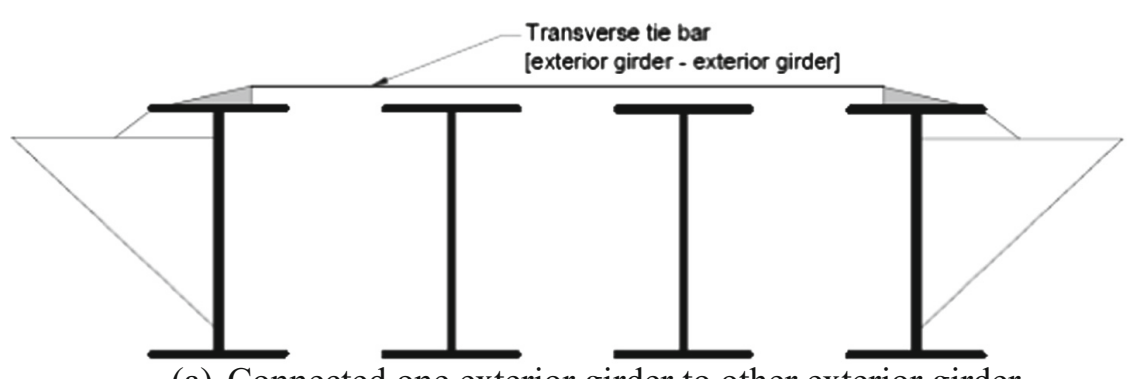

(a) Connected one exterior girder to other exterior girder

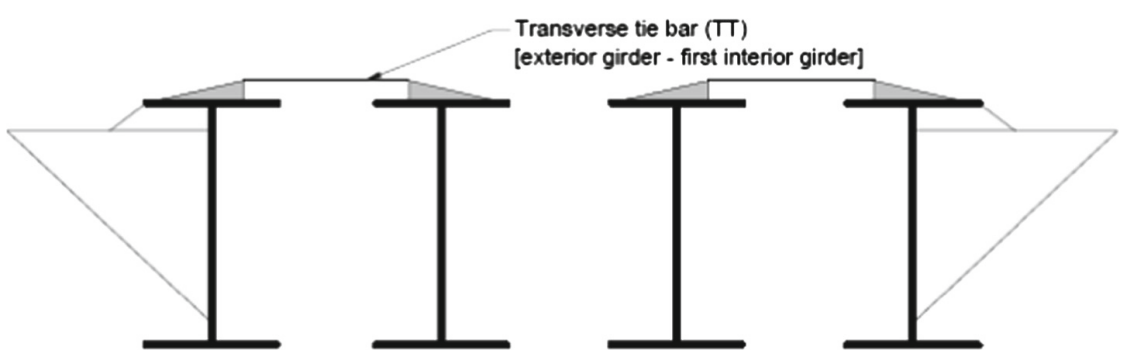

(b) Connected from exterior girder to first interior girder

Fig. 5. Schematic view of transverse tie bar

\section{Unadjusted Biagonal Tie Bar (UDT)}

During installation of the diagonal tie bars, S-shaped bending (as shown in Fig. 6) can be found due to the inability to adjust the angle of the tie bars which connects the top exterior girder flange to the bottom flange of the first interior girder (Ashiquzzaman et al. 2016).

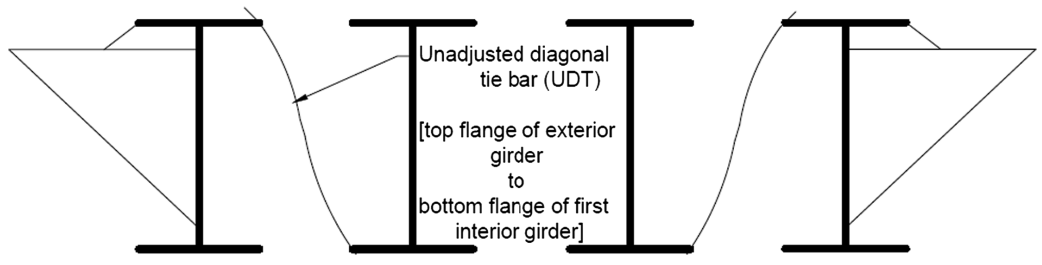

Fig. 6. Unadjusted tie bar with S-shaped bending 


\section{Adjusted/Straight Diagonal Tie Bar (ADT)}

In order to make adjusted diagonal tie bars as shown in Fig. 7, the hangers were modified as per the required angle.



Fig. 7. Adjusted tie bar

\section{Compression Strut}

Three different types of compression struts were tested in this study including (1) $10 \mathrm{~cm} \times 10 \mathrm{~cm}(4$ in. $\times 4$ in.) timber blocks $(\mathrm{TB})$ placed between girders on the bottom flange (shown in Fig. 8), (2) horizontal pipes with a diameter of $3.81 \mathrm{~cm}$ (1.5 in.) placed between the two girders at the bottom of the web (shown in Fig. 8), and (3) diagonal pipes (DP), as shown in Fig. 9, with a diameter of $6 \mathrm{~cm}$ (2.375 in.) and placed between the bottom flange of the exterior (loaded) girder and the top flange of the interior (non-loaded) girder.

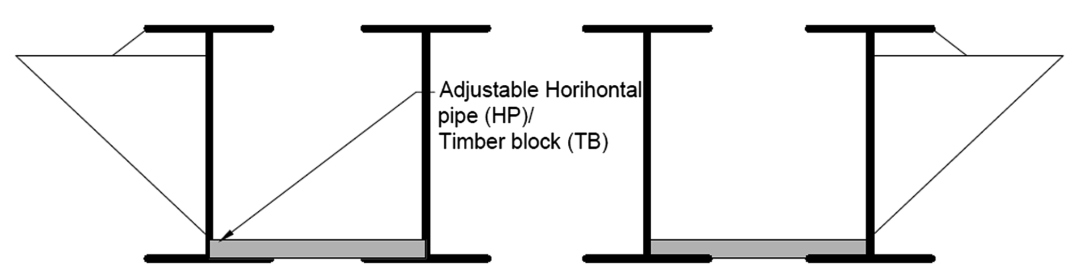

Fig. 8. Horizontal pipe (HP) and timber block (TB)

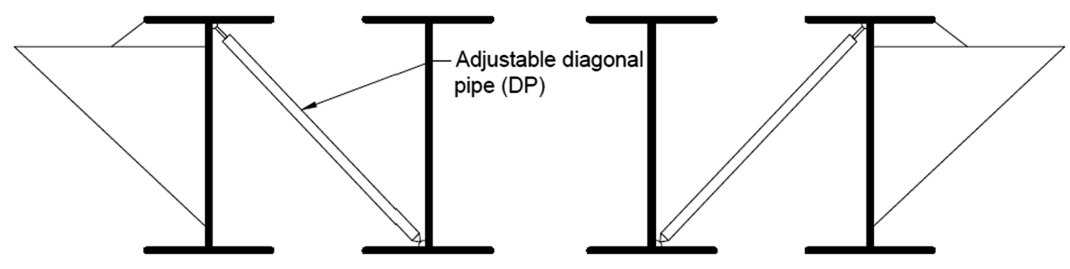

Fig. 9. Diagonal pipe (DP)

\section{Intermediate Cross Frames}

Two different cross frame configurations were tested including (1) one cross frame either at mid span or offset from mid span by $107 \mathrm{~cm}(3.5 \mathrm{ft}$.) on either side of the setup, and (2) two cross frames each located $107 \mathrm{~cm}$ (3.5 ft.) from mid span. Schematic views of the intermediate cross frames are shown in Fig. 10. 


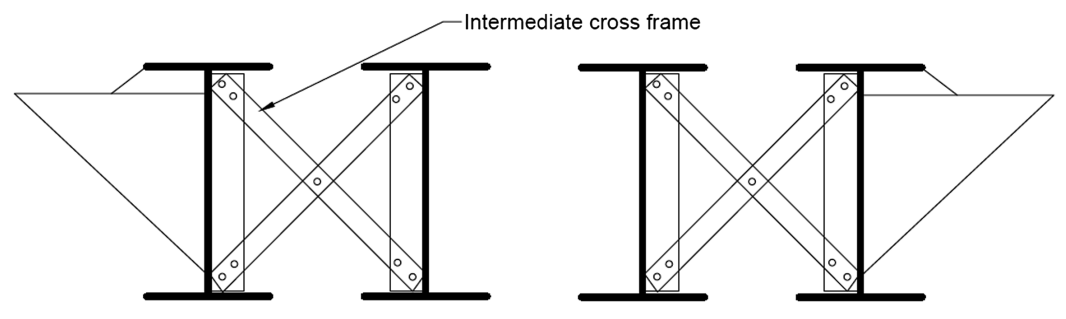

Fig. 10. Intermediate cross frame $(\mathrm{CF})$

Combined application of tie bars and compression struts is the conventional practice in bridge construction to prevent exterior girder rotation.

\section{Test Matrix}

Forty-five test cases were evaluated, shown in matrix form in Tables 1, 2, 3 and 4.

Table 1. Test designations for Groups 1,2 and 3



\section{Experimental Results}

Rotation results for the 45 cases tested are illustrated in Figs. 11, 12, 13, 14, 15, 16, 17 , 18 and 19. 
Table 2. Test designations for Groups 4, 5 and 6

\begin{tabular}{|c|c|c|c|c|c|c|c|c|}
\hline \multicolumn{3}{|c|}{$\begin{array}{l}\text { Group 4: 4-Adjusted Diagonal Tie } \\
\text { Bars (4TT) combined with other } \\
\text { elements }\end{array}$} & \multicolumn{3}{|c|}{$\begin{array}{l}\text { Group 5: 3-Adjusted Diagonal } \\
\text { Tie Bars (3TT) combined with } \\
\text { other elements }\end{array}$} & \multicolumn{3}{|c|}{$\begin{array}{c}\text { Group 6: 4-Unadjusted Diagonal } \\
\text { Tie Bars (4UDT) combined with } \\
\text { other elements }\end{array}$} \\
\hline $\begin{array}{l}\text { Primary } \\
\text { Bracing } \\
\text { Element }\end{array}$ & \begin{tabular}{|c|} 
Secondary \\
Bracing \\
Element
\end{tabular} & $\begin{array}{l}\text { Test } \\
\text { Label }\end{array}$ & $\begin{array}{l}\text { Primary } \\
\text { Bracing } \\
\text { Element }\end{array}$ & $\begin{array}{l}\text { Secondary } \\
\text { Bracing } \\
\text { Element }\end{array}$ & $\begin{array}{l}\text { Test } \\
\text { Label }\end{array}$ & $\begin{array}{l}\text { Primary } \\
\text { Bracing } \\
\text { Element }\end{array}$ & $\begin{array}{l}\text { Secondary } \\
\text { Bracing } \\
\text { Element }\end{array}$ & $\begin{array}{l}\text { Test } \\
\text { Label }\end{array}$ \\
\hline \multirow{5}{*}{$4 \mathrm{ADT}$} & --- & Only 4ADT & \multirow{5}{*}{ 3ADT } & --- & $\begin{array}{l}\text { Only } \\
\text { 3ADT }\end{array}$ & \multirow{5}{*}{ 4UDT } & --- & $\begin{array}{l}\text { Only } \\
\text { 4UDT }\end{array}$ \\
\hline & $\begin{array}{l}4 \mathrm{~TB} \\
4 \mathrm{HP}\end{array}$ & $\frac{4 \mathrm{ADT}+4 \mathrm{~TB}}{4 \mathrm{ADT}+4 \mathrm{HP}}$ & & $3 \mathrm{~TB}$ & $3 \mathrm{ADT}+$ & & $4 \mathrm{~TB}$ & 4UDT + \\
\hline & 4DP & $4 \mathrm{ADT}+4 \mathrm{DP}$ & & $3 \mathrm{HP}$ & $\begin{array}{l}3 \mathrm{ADT}+ \\
3 \mathrm{HP}\end{array}$ & & $4 \mathrm{HP}$ & $\begin{array}{c}4 \mathrm{UDT}+ \\
4 \mathrm{HP}\end{array}$ \\
\hline & 1DP@MS & $\begin{array}{c}\text { 4ADT + } \\
1 \mathrm{DP} @ \mathrm{MS}\end{array}$ & & \multirow[t]{2}{*}{$3 \mathrm{DP}$} & $\begin{array}{c}3 \mathrm{ADT}+ \\
3 \mathrm{DP}\end{array}$ & & \multirow[t]{2}{*}{ 4DP } & \multirow[t]{2}{*}{$\begin{array}{l}\text { 4UDT + } \\
\text { 4DP }\end{array}$} \\
\hline & 2DP & $4 \mathrm{ADT}+2 \mathrm{DP}$ & & & & & & \\
\hline \multicolumn{9}{|c|}{$\begin{array}{l}\text { - } @ \mathrm{MS}=\text { at mid span location } \\
\text { - } \quad \text { Arrangements of 4-TB/DP/HP/ADT/UDT are shown in Table } 1 . \\
\text { - } \quad \text { Arrangements of 3-TB/DP/HP/ADT/UDT are shown in Table } 1 .\end{array}$} \\
\hline
\end{tabular}

Table 3. Test designations for Groups 7 and 8

\begin{tabular}{|c|c|c|c|c|c|}
\hline \multicolumn{3}{|c|}{$\begin{array}{l}\text { Group 7: 3-Unadjusted Diagonal Tie Bars } \\
\text { (3UDT) combined with other elements }\end{array}$} & \multicolumn{3}{|c|}{$\begin{array}{c}\text { Group 8: 2-Cross Frames (2CF) combined with } \\
\text { other elements }\end{array}$} \\
\hline $\begin{array}{l}\text { Primary } \\
\text { Bracing } \\
\text { Element }\end{array}$ & $\begin{array}{c}\text { Secondary } \\
\text { Bracing } \\
\text { Element }\end{array}$ & $\begin{array}{l}\text { Test } \\
\text { Label }\end{array}$ & $\begin{array}{l}\text { Primary } \\
\text { Bracing } \\
\text { Element }\end{array}$ & $\begin{array}{c}\text { Secondary } \\
\text { Bracing } \\
\text { Element }\end{array}$ & $\begin{array}{l}\text { Test } \\
\text { Label }\end{array}$ \\
\hline \multirow{4}{*}{ 3UDT } & --- & Only 3UDT & \multirow{4}{*}{$2 \mathrm{CF}$} & ---- & Only 2CF \\
\hline & $3 \mathrm{~TB}$ & \multirow{2}{*}{$4 \mathrm{UDT}+3 \mathrm{~TB}$} & & $\begin{array}{l}4 \mathrm{TT} \\
\mathrm{TTT}\end{array}$ & $\frac{2 \mathrm{CF}+4 \mathrm{TT}}{2 \mathrm{CF}+3 \mathrm{TT}}$ \\
\hline & $3 \mathrm{HP}$ & & & $\frac{311}{4 \mathrm{ADT}}$ & $2 \mathrm{CF}+4 \mathrm{ADT}$ \\
\hline & $3 \mathrm{DP}$ & $3 \mathrm{UDT}+3 \mathrm{DP}$ & & 3ADT & $2 \mathrm{CF}+3 \mathrm{ADT}$ \\
\hline \multicolumn{6}{|c|}{$\begin{array}{l}\text { - Arrangements of 4-TB/DP/HP/TT/ADT/UDT are shown in Table } 1 . \\
\text { - }\end{array}$ Arrangements of 3-TB/DP/HP/TT/ADT/UDT are shown in Table 1.} \\
\hline \multicolumn{4}{|c|}{ - 2-CFs are located at $\mathrm{y}=1.06 \mathrm{~m}$ apart from MS } & $-y \rightarrow$ & \\
\hline \multicolumn{6}{|c|}{$M S$} \\
\hline
\end{tabular}

\section{Group 1 (No Bracing System)}

The measured rotation for this case is $2.73^{\circ}$ (Fig. 11) which is the largest rotation observed during testing. This is the worst case scenario for the exterior girder since there are no rotation prevention systems available to resist the rotation resulting from the applied load.

\section{Group 2 and 3 (Transverse Ties Combined with Additional Bracing Elements)} As per Figs. 12 and 13, using only transverse tie bars as a girder rotation prevention system works well to prevent rotation effectively. Adding timber blocks or horizontal pipes cannot effectively reduce the girder rotation. It can be seen from Figs. 12 and 13, 
Table 4. Test designations for Group 9

\begin{tabular}{|c|c|c|c|c|c|}
\hline \multicolumn{6}{|c|}{ Group 9: 1-Intermediate Cross Frame (1CF) combined with other elements } \\
\hline $\begin{array}{l}\text { Primary } \\
\text { Bracing } \\
\text { Element }\end{array}$ & $\begin{array}{l}\text { Secondary } \\
\text { Bracing } \\
\text { Element }\end{array}$ & $\begin{array}{l}\text { Test } \\
\text { Label }\end{array}$ & $\begin{array}{c}\text { Primary } \\
\text { Bracing } \\
\text { Element }\end{array}$ & $\begin{array}{c}\text { Secondary } \\
\text { Bracing } \\
\text { Element }\end{array}$ & $\begin{array}{c}\text { Test } \\
\text { Label }\end{array}$ \\
\hline \multirow{8}{*}{$1 \mathrm{CF} @ \mathrm{MS}$} & --- & Only 1CF@MS & \multirow{8}{*}{$\begin{array}{c}1 \mathrm{CF} \\
\mathrm{N} @ \mathrm{MS}\end{array}$} & \multirow{3}{*}{---} & \multirow{3}{*}{$\begin{array}{c}\text { Only } 1 \mathrm{CF} \\
\mathrm{N} @ \mathrm{MS}\end{array}$} \\
\hline & 4TT & $1 \mathrm{CF} @ \mathrm{MS}+4 \mathrm{TT}$ & & & \\
\hline & 3TT & $1 \mathrm{CF} @ \mathrm{MS}+3 \mathrm{TT}$ & & & \\
\hline & 2TT & $1 \mathrm{CF} @ \mathrm{MS}+2 \mathrm{TT}$ & & & \multirow{2}{*}{$\begin{array}{c}\text { 1CF N@MS + } \\
\text { 2DP }\end{array}$} \\
\hline & 2DP & 1CF@MS + 2DP & & 2DP & \\
\hline & $2 \mathrm{DP}+3 \mathrm{TT}$ & $1 \mathrm{CF} @ \mathrm{MS}+2 \mathrm{DP}+3 \mathrm{TT}$ & & \multirow{3}{*}{$2 \mathrm{DP}+3 \mathrm{TT}$} & \multirow{3}{*}{$\begin{array}{c}\text { 1CF N@MS + } \\
\text { DP + 3TT }\end{array}$} \\
\hline & 4ADT & $1 \mathrm{CF} @ \mathrm{MS}+4 \mathrm{ADT}$ & & & \\
\hline & 2ADT & $1 \mathrm{CF} @ \mathrm{MS}+2 \mathrm{ADT}$ & & & \\
\hline \multicolumn{6}{|c|}{ 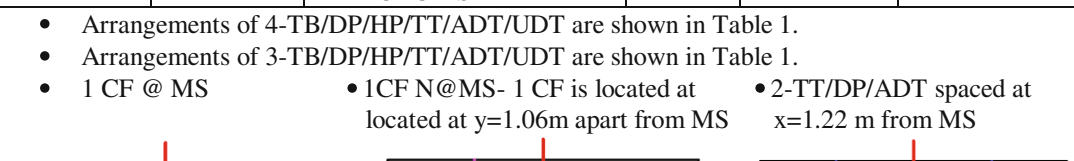 } \\
\hline & & $-y-1$ & & & \\
\hline & & Ms & & & Ms \\
\hline
\end{tabular}

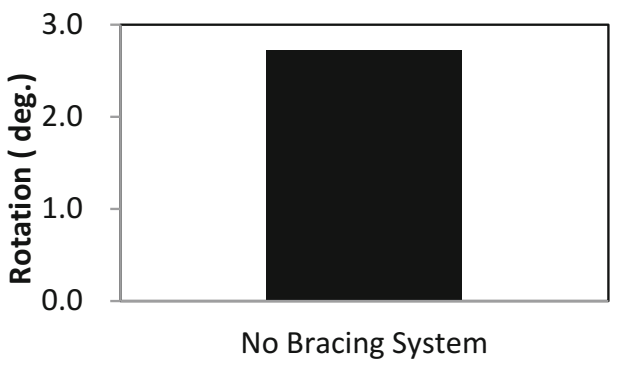

Fig. 11. Group 1: no bracing system

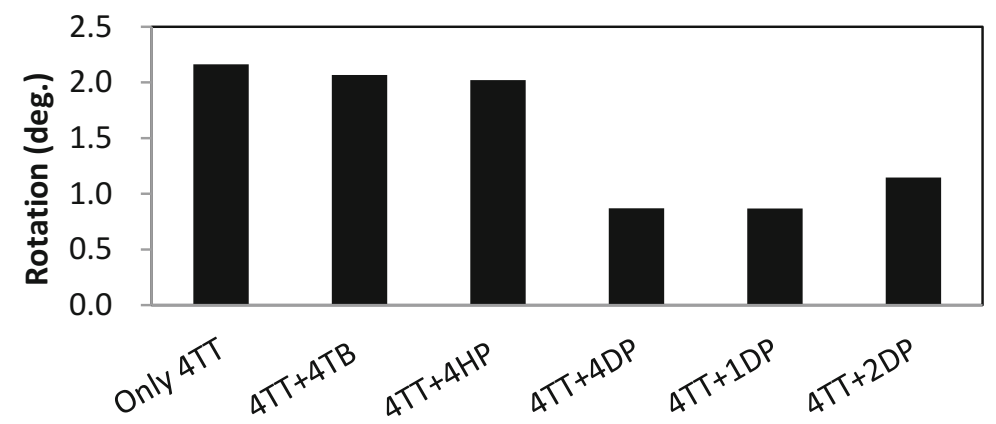

Fig. 12. Group 2: $4 \mathrm{TT}+$ other bracing elements 


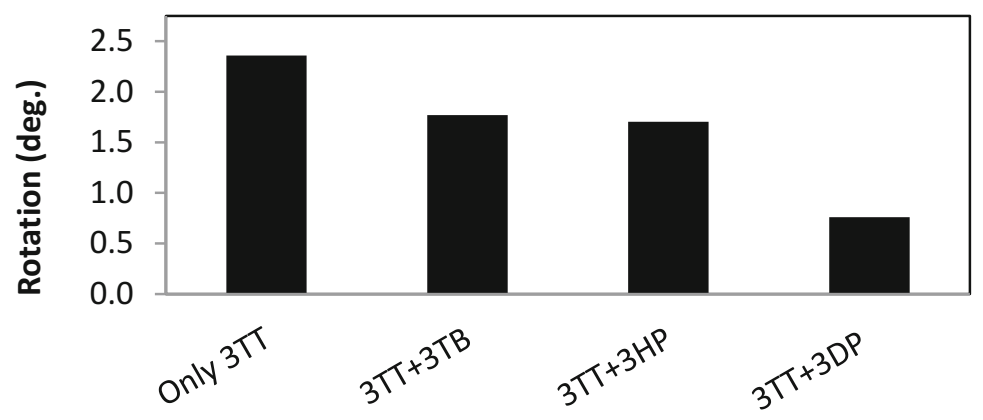

Fig. 13. Group 3: 3TT + other bracing elements

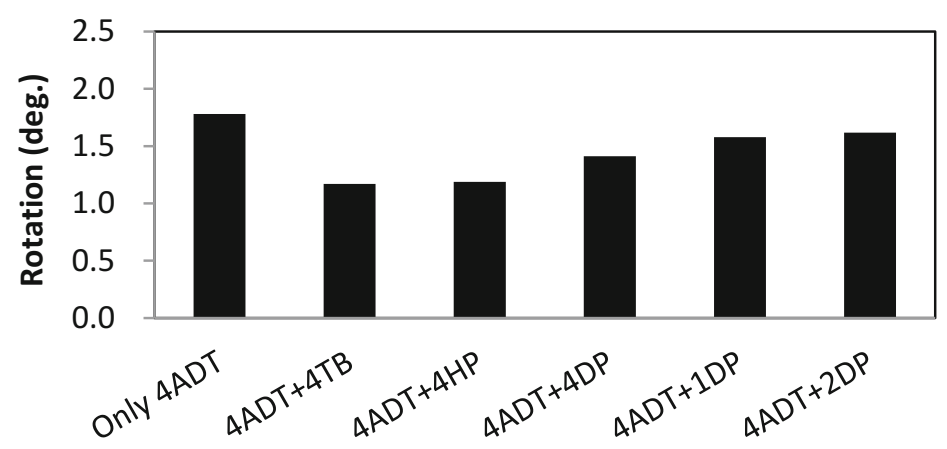

Fig. 14. Group 4: 4ADT + other bracing elements

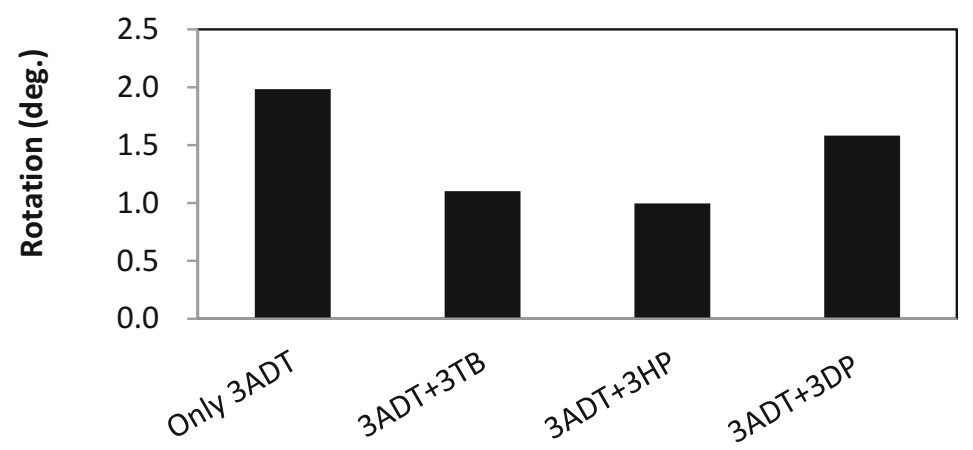

Fig. 15. Group 5: $3 \mathrm{ADT}+$ other bracing elements

the combination of transverse tie bars and diagonal pipes can effectively reduce the exterior girder rotation by approximately $60 \%$ as compared with the conventional rotation prevention system $(\mathrm{TT}+\mathrm{TB})$. The lowest measured rotations were $0.87^{\circ}$ and $0.76^{\circ}$ for the $4 \mathrm{TT}+4 \mathrm{DP}$ (Group 2) and 3TT $+3 \mathrm{DP}$ (Group 3) configurations, respectively. 


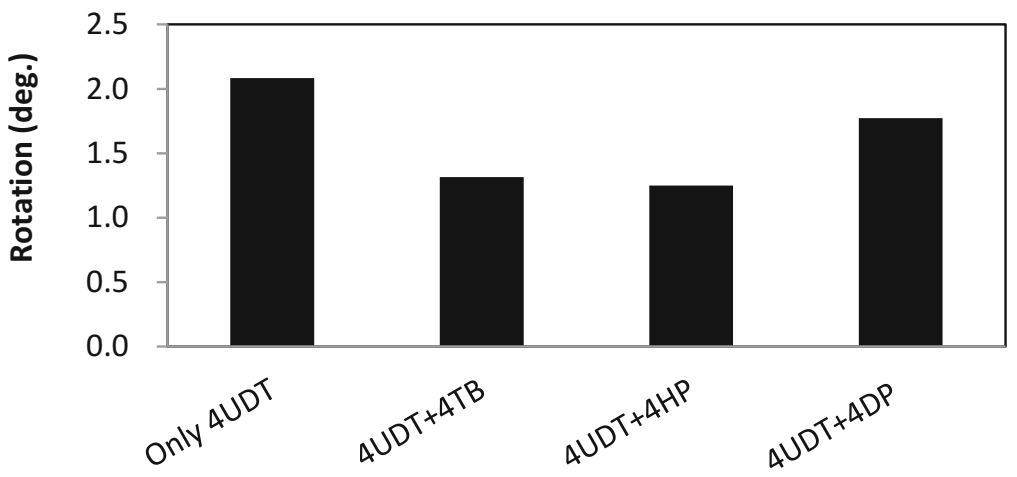

Fig. 16. Group 6: 4UDT + other bracing elements

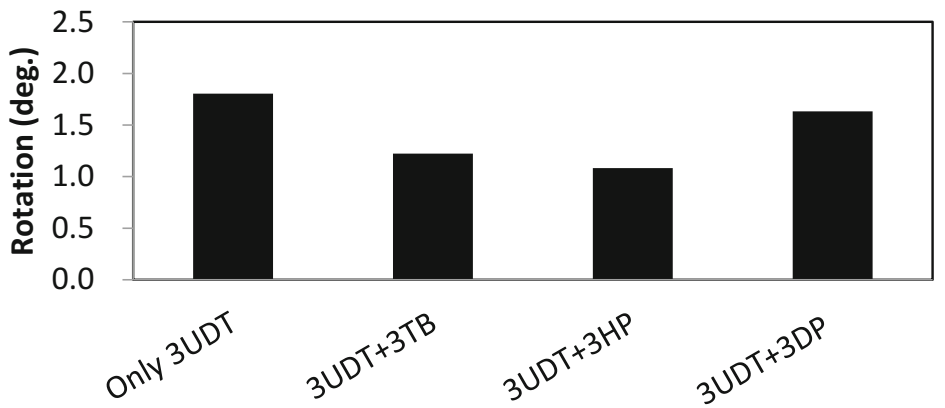

Fig. 17. Group 7: 3UDT + other bracing elements

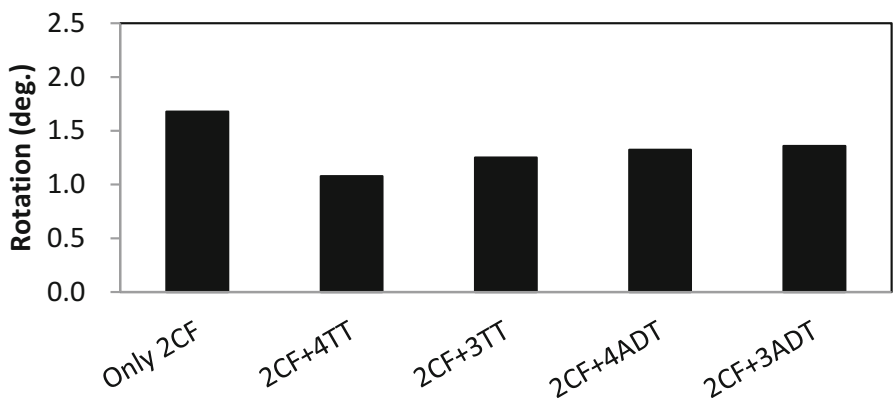

Fig. 18. Group 8: $2 \mathrm{CF}+$ other bracing elements

\section{Group 4 and 5 (Adjusted Diagonal Ties Combined with Additional Bracing Elements)}

As shown in Figs. 14 and 15, adjusted diagonal tie bars show similar characteristics as the transverse tie bars without compression struts. Applying only adjusted diagonal tie bars shows the maximum girder rotation in Groups 4 and 5. Adding horizontal pipes 




Fig. 19. Group 9: $1 \mathrm{CF}+$ other bracing elements

and timber blocks with adjusted diagonal tie bars can reduce the rotation by approximately 50\% when compared with conventional rotation prevention systems (TT + TB). It is suggested by the researchers that using horizontal pipes works better than timber blocks. The horizontal pipes are easier to install and do not require shimming during installation of the blocks. The lowest experimental rotations were $1.18^{\circ}$ and $1.00^{\circ}$ for the $4 \mathrm{ADT}+4 \mathrm{HP}$ (Group 4) and $3 \mathrm{ADT}+3 \mathrm{HP}$ (Group 5) configurations, respectively.

\section{Group 6 and 7 (Unadjusted Diagonal Ties Combined with Additional Bracing Elements)}

The installation of this type of unadjusted diagonal tie bars was a complex task for the researchers and time consuming as well. S-shaped bending as shown in Fig. 6 introduces initial defect in the unadjusted diagonal tie bars. Based on the results as shown in Figs. 16 and 17, the initial defect due to S-shaped bending made them ineffective in preventing rotation.

\section{Group 8 (Two Cross Frames Combined with Additional Bracing Elements)}

In this group, two intermediate cross frames located $107 \mathrm{~cm}(3.5 \mathrm{ft}$.) from mid span increase the overall stiffness of the structure. In this group, the significance of tension carrying member (transverse tie bars and adjusted diagonal tie bars) was recognized. The $2 \mathrm{CF}+4 \mathrm{TT}$ configuration shows the lowest rotation $\left(1.08^{\circ}\right)$ in the group. As shown in Fig. 18, adding two intermediate cross frames reduces the exterior girder rotation by $50 \%$ as compared with the conventional rotation prevention system $(\mathrm{TT}+\mathrm{TB})$.

\section{Group 9 (One Cross Frame Combined with Additional Bracing Elements)}

In this group, one intermediate cross frame with two different configurations was used including (1) one intermediate cross frame located at mid span (CF@MS), and (2) one intermediate cross frame located at $107 \mathrm{~cm}$ (3.5 ft.) from mid span which was identified as cross frame not at mid span (CF N@MS). When the CF@MS are combined with 3 
or $4 \mathrm{TT}$, a $50 \%$ reduction in the rotation is observed when compared with the system containing only one cross frame. These results demonstrate that the combination of 1-CF at mid span plus TT is an extremely effective method to decrease rotation. 1CF $\mathrm{N} @ \mathrm{MS}$ did not perform well alone. Adding transverse tie bars reduced the girder rotation effectively.

\section{Clonclusions}

Based on the experimental study, the following conclusions can be drawn:

- The conventional rotation prevention systems $(\mathrm{TT}+\mathrm{TB}$ or UDT $+\mathrm{TB})$ are not effective in preventing rotation during overhang bridge deck construction.

- The TT + DP, ADT + HP, or intermediate cross frames at the exterior panels configurations are improved alternatives compared to the current practice.

- The improved rotation prevention systems can reduce rotations by up to $50 \%$ compared with the conventional girder rotation prevention systems.

Acknowledgement. This project was made possible through funding from the Illinois Department of Transportation (IDOT) through the Illinois Center of Transportation (ICT); this support is very much appreciated. The authors would also like to thank Mr. Darren Green, Carlos Merino Calvo, SLU, for his help throughout this study.

\section{References}

Ariyasajjakorn, D.: Full Scale Testing of Overhang Falsework Hanger on NCDOT Modified Bulb Tee (MBT) Girders. Master's thesis, North Carolina State University, North Carolina (2006)

Ashiquzzaman, Md., Hui, L., Schmeltz, J., Merino, C., Bozkurt, B., Ibrahim, A., Lindquist, W., Hindi, R.: Effectiveness of exterior beam rotation prevention systems for bridge deck construction. Report no. FHWA-ICT-16-015, Illinois Department of Transportation, Springfield, Illinois (2016)

Clifton, S.: Bridge Deck Overhang Construction. Master's thesis, University of Texas at Austin, Texas (2008)

Clifton, S., Bayrak, O.: Bridge Deck Overhang Construction. Report no. IAC 88-5DD1A003-2, Texas Department of Transportation, Austin, Texas (2008)

Dayton Superior Corporation: Bridge Deck Handbook 2015 (2015). http://www.daytonsuperior. com/docs/default-source/handbooks/ds_bridge_deck_hb.pdf?sfvrsn=20. Accessed 12 Feb 2016

Fasl, J.: The Influence of Overhang Construction on Girder Design. Master's thesis, University of Texas at Austin, Texas (2008)

Gupta, V.K., Okui, Y., Nagai, M.: Development of web slenderness limits for composite I-girders accounting for initial bending moment. Struct. Eng./Earthq. Eng. 23(2), 229S-239S (2006)

Haskett, M., Oehlers, D.J., Ali, M.M., Wu, C.: Rigid body moment-rotation mechanism for reinforced concrete beam hinges. Eng. Struct. 31(5), 1032-1041 (2009) 
Kala, Z., Kala, J., Melcher, J., Skaloud, M., Omishore A.: Imperfections in steel plated structures-should we straighten their plate elements? In: Nordic Steel Construction Conference NSCC 2009, 2-4 September, Malmo, Sweden, pp. 552-555 (2009)

Lackey, P.: An Investigation of Bridge Deck Overhang Falsework Systems Installed onto Bulb Tee Girders. Thesis, North Carolina State University, North Carolina (2006)

Sayed-Ahmed, E.Y.: Lateral torsion-flexure buckling of corrugated web steel girders. Proc. Inst. Civ. Eng. Struct. Build. 158(1), 53-69 (2005)

Shokouhian, M., Shi, Y.: Flexural strength of hybrid steel I-beams based on slenderness. Eng. Struct. 93, 114-128 (2015)

Yang, S., Helwig, T., Klingner, R., Engelhardt, M., Fasl, J.: Impact of Overhang Construction on Girder Design. Report no. FHWA/TX-10/0-5706-1, Texas Department of Transportation, Austin, Texas (2010) 